Vol. 1 No. 3 Juli 2021 e-ISSN : 2774-6283 | p-ISSN : 2775-0019

\title{
UPAYA MENINGKATKAN KEMAMPUAN MEMAHAMI \\ KARAKTERISTIK SENSOR PADA ENGINE BENSIN MELALUI MODEL KERJA KELOMPOK DENGAN TEKNIK JIGSA $W$ PADA PESERTA DIDIK KELAS XI OTOTRONIK DI SMK NEGERI 6 MALANG
}

\author{
IRFAN HAMDANI \\ SMK Negeri 6 Malang \\ e-mail: irfanhamdani978@gmail.com
}

\begin{abstract}
ABSTRAK
Mata Pelajaran Perawatan Perbaikan Engine Mananagement System dan Motor Listrik yang diberikan pada peserta didik sekolah menengah kejuruan (SMK) terdiri dari pengajaran teori dan praktek, yqng mempunyai tingkat kesulitan yang lebih tinggi dibandingkan yang konvensional. Hal ini terbukti dengan tingkat ketercapaian kompetensi minimal pada mata pelajaran ini, khususnya pada kompetensi dasar memahami karakteristik sensor pada engine bensin dan mengukur besaran listrik sensor pada engine bensin, menunjukkan hasil belajar yng rendah $(30 \%$ dari jumlah peserta didik yang mencapai KKM). Salah satu aspek yang berpengaruh terhadap rendahnya hasil ketercapaian belajar peserta didik adalah kekurangaktifan dalam proses belajar mengajar. Dan dengan pendekatan pembelajaran yang berorientasi konstruktivistik akan memberikan pengalaman belajar yang bermakna dan memberi peluang kepada peserta didik untuk mengaktualisasikan diri. Sehingga peserta didik akan lebih aktif dalam belajar dan memaksimalkan hasil belajar. Adapun model pembelajaran yang sesuai untuk tujuan tersebut adalah model kerja kelompok dengan teknik Jigsaw. Kegiatan yang dilakukan pada model pembelajaran ini adalah sebagai berikut: 1. kegiatan membaca untuk menggali informasi, 2) diskusi kelompok ahli, 3) laporan kelompok, 4) kuis dilakukan mencakup semua topik permasalahan yang dibicarakan, 5) perhitungan sekor kelompok dan menetukan penghargaan kelompok. Hal ini terbukti dari adanya peningkatan hasil belajar dari sebelum dilakukan tindakan dan tiap siklusnya, yaitu (1)sebelum dilakukan tindakan persentase kelulusan $30 \%$, (2) pada siklus I persentase kelulusan $60 \%$, dan (3) pada siklus II persentase kelulusan $75 \%$. Selain itu, tingkat pemahaman peserta didik secara individu semakin baik dilihat dari semakin mengecilnya angka deviasi antara nilai bawah dan atas pada setiap periode penilaian, yaitu sebelum tindakan sebesar 43, siklus I sebesar 40, dan siklus II sebesar 25.
\end{abstract}

Kata Kunci: Meningkatkan Kemampuan, Kerja Kelompok, Jigsaw

\section{PENDAHULUAN}

Mata Pelajaran Perawatan Perbaikan Engine Mananagement System dan Motor Listrik yang diberikan pada peserta didik sekolah menengah kejuruan (SMK) terdiri dari pengajaran teori dan praktek. Dan berdasarkan kurikulum 2013 revisi 2017 standar isi, mata pelajaran ini diberikan di kelas XI semester 3 dan 4 yang mempunyai tingkat kesulitan yang lebih tinggi dibandingkan yang konvensional. Untuk mengukur tingkat ketercapaian kemampuan yang diperoleh peserta didik (KKM) bila mendapatkan 70. Hal ini tergambar dari tingkat ketercapaian kompetensi minimal pada mata pelajaran ini, khususnya pada kompetensi dasar memahami karakteristik sensor pada engine bensin dan mengukur besaran listrik sensor pada engine bensin, di kelas XI Oto menunjukkan hasil belajar rendah ( $30 \%$ dari jumlah peserta didik yang mencapai KKM).

Permasalahan yang terjadi pada proses pembelajaran pada materi karakteristik sensor engine bensin adalah banyak dari peserta didik mengalami kesulitan dalam memahami karakteristik sensor pada engine bensin dan mengukur besaran listrik. Peserta didik masih lemah dalam pemahaman tentang fungsi sensor dan cara kerjanya pada engine bensin yang menggunakan sistem injeksi. Hal ini yang menyebabkan keaktifan peserta didik rendah.

Selain faktor peserta didik, permasalahan dapat pula ditinjau dari pendekatan proses belajar mengajar yang diterapkan oleh guru, dalam hal ini berkaitan dengan metode/model 
belajar yang digunakan. Berdasarkan refleksi yang dilakukan, dalam mengantarkan pembelajaran guru masih melakukan proses belajar mengajar yang berpusat pada guru. Sehingga peserta didik tidak secara aktif dilibatkan dalam proses belajar mengajar.

Dari permasalahan tersebut dicoba untuk menerapkan model pembelajaran yang memungkinkan guru melaksanakan pembelajaran berpusat pada peserta didik, yaitu model pembelajaran kooperatif dengan jigsaw. Model pembelajaran kooperatif teknik jigsaw adalah sebuah model belajar kooperatif yang menitik beratkan kepada kerja kelompok peserta didik dalam bentuk kelompok kecil, seperti yang diungkapkan Lie ( 2008: 73), bahwa pembelajaran kerja kelompok dengan teknik jigsaw ini merupakan model belajar kooperatif dengan cara peserta didik belajar dalam kelompok kecil yang terdiri atas empat sampai dengan enam orang secara heterogen dan peserta didik bekerja sama salaing ketergantungan positif dan bertanggung jawab secara mandiri. Sebagaimana yang diungkapkan Rusman ( 2008 : 203 ), bahwa dengan teknik jigsaw peserta didik memiliki banyak kesempatan untuk mengemukanakan pendapat, dan mengelolah informasi yang didapat dan dapat meningkatkan keterampilan berkomunikasi, anggota kelompok bertanggung jawab atas keberhasilan kelompoknya dan ketuntasan bagian materi yang dipelajari, dan dapat menyampaikan kepada kelompoknya.

Pembelajaran dengan model pembelajaran kerja kelompok dengan teknik jigsaw guru sebagai fasilitator, yaitu mengarahkan atau meluruskan bila ada pemahaman yang belum tepat. Pada pendekatan ini peserta didik akan dihadapkan pada tugas yang relevan untuk diselesaikan baik melalui diskusi kelompok maupun secara individual agar mampu menyelesaikan masalah dan menarik suatu kesimpulan. Maka guru membagi peserta didik menjadi 6 kelompok, dengan 4/5 siswa dalam setiap kelompoknya. Dan dari setiap kelompok ditunjuk satu orang sebagai staf ahli yang tergabung dalam kelompok ahli ( expert gruop).

Secara teknik langkah-langkah pembelajaran yang dilakukan meliputi : a) merancang Rencana Pelaksanaan Pembelajaran berorientasi model kerja kelompok dengan teknik jigsaw, b) menerapkan Rencana Pelaksanaan Pembelajaran dilanjutkan dengan evaluasi dan refleksi pada setiap akhir tatap muka.

\section{METODE PENELITIAN}

Pada penelitian tindakan kelas yang dilakukan menggunakan pendekatan kuantitatif dan kualitatif, yang proses penelitiannya tampak pada rangkaian tahapan yang dilakukan pada setiap siklus . Adapun tahapan setiap siklus pada penelitian ini tergambar sebagai berikut.

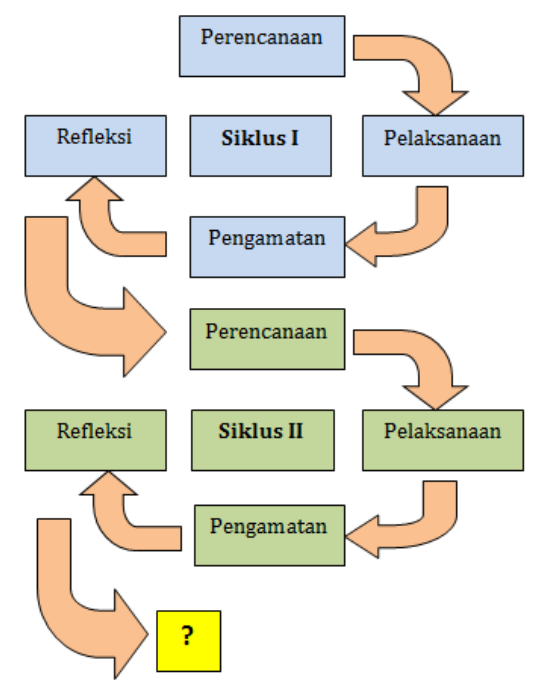

\section{Gambar 1 Alur Penelitian Tindakan Kelas}

Pada tahapan penelitian di siklus yang pertama, guru membuat rencana dengan 


\section{Vol. 1 No. 3 Juli 2021 e-ISSN : 2774-6283 | p-ISSN : 2775-0019}

menyiapkan perangkat pembelajaran berupa silabus, rencana pelaksanaan pembelajaran, hand out, lembar kerja peserta didik, lembar observasi keaktifan, lembar angket respon peserta didik, lembar observasi pelaksanaan pembelajaran kerja kelompok dengan teknik Jigsaw. Setelah itu, dilakukan tindakan yaitu dengan melaksanakan proses belajar mengajar dengan menerapkan model belajar yang ditentukan dan dilakukan pengamatan oleh guru lain. Selanjutnya dilakukan refleksi, sebagai bahan untuk melakukan tahapan di siklus berikutnya dengan materi dengan kompetensi dasar yang lain.

\section{HASIL DAN PEMBAHASAN}

\section{A. Hasil}

Setelah memperoleh tindakan pembelajaran melalui model kerja kelompok dengan teknik jigsaw sebanyak dua siklus, aktivitas belajar peserta didik dalam memahami sensor pada engine bensin mengalami peningkatan yang signifikan. Hal ini tampak pada tabel berikut ini.

Tabel 1 Peningkatan Aktivitas Peserta Didik (Pra Siklus, Siklus I, Siklus II)

\begin{tabular}{|c|c|c|c|}
\hline Kegiatan & Pra Siklus & Siklus I & Siklus II \\
\hline $\begin{array}{l}\text { Awal kegiatan } \\
\text { pembelajaran }\end{array}$ & $\begin{array}{l}\text { Banyak peserta } \\
\text { didik menunjukkan } \\
\text { sikap belum siap } \\
\text { memulai pelajaran }\end{array}$ & $\begin{array}{l}\text { Melalui arahan guru, } \\
\text { tampak terjadi } \\
\text { perubahan sikap oleh } \\
\text { sebagian besar peserta } \\
\text { didik untuk siap } \\
\text { belajar }\end{array}$ & $\begin{array}{l}\text { Peserta didik } \\
\text { menerima baik } \\
\text { kehadiran guru dan } \\
\text { ada perubuhan sikap } \\
\text { pada sebagian besar } \\
\text { peserta didik untuk } \\
\text { memulai pembelajaran }\end{array}$ \\
\hline $\begin{array}{l}\text { Pengarahan oleh } \\
\text { guru untuk perihal } \\
\text { belajar yang akan } \\
\text { dilakukan }\end{array}$ & $\begin{array}{l}\text { Peserta didik } \\
\text { sebagian besar } \\
\text { kurang } \\
\text { memperhatikan } \\
\text { penjelasan guru } \\
\text { dan masih banyak } \\
\text { yang berbicara } \\
\text { dengan temannya }\end{array}$ & $\begin{array}{l}\text { Peserta didik diam } \\
\text { memperhatikan arahan } \\
\text { guru walaupun ada } \\
\text { beberapa peserta didik } \\
\text { yang perhatiannya } \\
\text { kurang terfokus pada } \\
\text { penjelasan guru }\end{array}$ & $\begin{array}{l}\text { Peserta didik } \\
\text { memberikan respon } \\
\text { secara positif arahan } \\
\text { guru dan ada } 3 \text { orang } \\
\text { peserta didik yang } \\
\text { bertanya untuk } \\
\text { melakukan klarifikasi }\end{array}$ \\
\hline $\begin{array}{l}\text { Penyajian masalah } \\
\text { pada lembar tugas } \\
\text { dan aktivitas yang } \\
\text { harus dilakukan }\end{array}$ & $\begin{array}{l}\text { Peserta didik } \\
\text { tampak kurang } \\
\text { responsif dan } \\
\text { menerima saja apa } \\
\text { yang ditugaskan } \\
\text { guru }\end{array}$ & $\begin{array}{l}\text { Peserta didik } \\
\text { menyampaikan } \\
\text { pertanyaan dan } \\
\text { mengungkapkan } \\
\text { kekhawatiran jika } \\
\text { tidak mampu } \\
\text { menyelesaikan semua } \\
\text { tugas }\end{array}$ & $\begin{array}{l}\text { Peserta didik } \\
\text { menerima tugas } \\
\text { tersebut dengan sikap } \\
\text { senang dan } \\
\text { menunjukkan sikap } \\
\text { antusias untuk segera } \\
\text { menyelesaikan tugas }\end{array}$ \\
\hline $\begin{array}{l}\text { Penugasan untuk } \\
\text { memahami } \\
\text { masalah dan } \\
\text { mmendiskusikan } \\
\text { dengan teman } \\
\text { kelompok } \\
\end{array}$ & $\begin{array}{l}\text { (Tahap ini tidak } \\
\text { dilakukan pada } \\
\text { pembelajaran } \\
\text { sebelumnya) }\end{array}$ & $\begin{array}{l}\text { Peserta didik } \\
\text { memahami tugas } \\
\text { tersebut secara } \\
\text { individual, tidak ada } \\
\text { keaktifan diskusi } \\
\text { antarteman }\end{array}$ & $\begin{array}{l}\text { Peserta didik } \\
\text { memahami masalah } \\
\text { dan mendiskusikannya } \\
\text { dengan teman } \\
\text { kelompoknya }\end{array}$ \\
\hline $\begin{array}{l}\text { Penemuan } \\
\text { jawaban masalah } \\
\text { dalam teks bacaan }\end{array}$ & $\begin{array}{l}\text { Peserta didik secara } \\
\text { individual } \\
\text { membaca teks yang } \\
\text { ada dalam buku } \\
\text { paket dan } \\
\text { menuliskan }\end{array}$ & $\begin{array}{l}\text { Peserta didik } \\
\text { membaca teks secara } \\
\text { sungguh-sungguh dan } \\
\text { secara individual } \\
\text { menuliskan jawaban, } \\
\text { sesekali bertanya } \\
\end{array}$ & $\begin{array}{l}\text { Peserta didik berusaha } \\
\text { menemukan jawaban } \\
\text { dan mendiskusikannya } \\
\text { untuk setiap butir } \\
\text { jawaban tugas. }\end{array}$ \\
\hline
\end{tabular}


VOCATIONAL : Jurnal Inovasi Pendidikan Kejuruan

Vol. 1 No. 3 Juli 2021 e-ISSN : 2774-6283 | p-ISSN : 2775-0019

\begin{tabular}{|c|c|c|c|}
\hline & $\begin{array}{l}\text { jawaban } \\
\text { pertanyaan bacaan }\end{array}$ & $\begin{array}{l}\text { kepada teman } \\
\text { kelompoknya }\end{array}$ & \\
\hline $\begin{array}{l}\text { Menuliskan } \\
\text { jawaban untuk } \\
\text { laporan tugas }\end{array}$ & $\begin{array}{l}\text { Peserta didik } \\
\text { melakukan secara } \\
\text { individual, tanpa } \\
\text { ada diskusi }\end{array}$ & $\begin{array}{l}\text { Setiap peserta didik } \\
\text { menuliskan jawaban } \\
\text { pertanyaan, tetapi } \\
\text { sebagian peserta didik } \\
\text { ada yang hanya } \\
\text { mencontek jawaban } \\
\text { temannya }\end{array}$ & $\begin{array}{l}\text { Setiap peserta didik } \\
\text { menuliskan jawaban } \\
\text { pertanyaan } \\
\text { berdasarkan informasi } \\
\text { yang dipeoleh dari } \\
\text { dskusi }\end{array}$ \\
\hline $\begin{array}{l}\text { Penyampaian } \\
\text { jawaban secara } \\
\text { klasikal sebagai } \\
\text { laporan tugas hasil } \\
\text { diskusi }\end{array}$ & $\begin{array}{l}\text { Lembar jawaban } \\
\text { pertanyaan } \\
\text { langsung } \\
\text { dikumpulkan } \\
\text { kepada guru }\end{array}$ & $\begin{array}{l}\text { Untuk menyampaikan } \\
\text { jawaban setiap butir } \\
\text { masalah, peserta didik } \\
\text { menunggu penunjukan } \\
\text { dari guru }\end{array}$ & $\begin{array}{l}\text { Tanpa menunggu } \\
\text { perintah guru, peserta } \\
\text { didik secara sukarela } \\
\text { menyampaikan } \\
\text { jawaban setiap butir } \\
\text { masalah }\end{array}$ \\
\hline $\begin{array}{l}\text { Pengumpulan } \\
\text { lembar jawaban } \\
\text { tugas }\end{array}$ & $\begin{array}{l}\text { Ada } 6 \text { peserta didik } \\
\text { tidak } \\
\text { mengumpulkan } \\
\text { lembar jawaban } \\
\text { sehingga diberi } \\
\text { nilai } 0\end{array}$ & $\begin{array}{l}\text { Semua peserta didik } \\
\text { mengumpulkan } \\
\text { lembar jawaban tugas } \\
\text { walaupun ada } \\
\text { sebagian peserta didik } \\
\text { yang butir jawabannya } \\
\text { tidak lengkap }\end{array}$ & $\begin{array}{l}\text { Semua peserta didik } \\
\text { mengumpulkan } \\
\text { lembar jawaban tugas } \\
\text { dan seluruh butir } \\
\text { masalah terdapat } \\
\text { jawabaannya }\end{array}$ \\
\hline
\end{tabular}

Selain itu, juga terjadi peningkatan yang signifikan tentang hasil belajar peserta didik dalam memahami sensor pada engine bensin dengan menggunakan model kerja kelompok dengan teknik jigsaw Hal ini tampak pada tabel berikut ini.

Tabel 2 Peningkatan Kemampuan Peserta Didik

\begin{tabular}{|l|l|l|l|l|}
\hline No & Aspek & Pra Siklus & Siklus I & Siklus II \\
\hline 1 & Nilai Terendah & 0 & 60 & 70 \\
\hline 2 & Nilai Tertinggi & 90 & 90 & 90 \\
\hline 3 & Rerata Nilai & 54,4 & 74 & 79,8 \\
\hline 4 & Ketuntasan Belajar & $24 \%$ & $60 \%$ & $92 \%$ \\
\hline 5 & Kemampuan Tinggi & $8 \%$ & $8 \%$ & $24 \%$ \\
\hline 6 & Kemampuan Sedang & $16 \%$ & $52 \%$ & $68 \%$ \\
\hline 7 & Kemampuan Rendah & $52 \%$ & $40 \%$ & $8 \%$ \\
\hline
\end{tabular}

\section{B. Pembahasan}

Pada siklus I, ketika dalam pembelajaran memahami sensor pada engine bensin, diterapkan model kerja kelompok dengan teknik jigsaw, aktivitas peserta didik mulai meningkat. Pada saat menerima arahan dari guru di awal pembelajaran, sebagian besar peserta didik menunjukkan perhatian yang baik. Beberapa orang peserta didik memberikan respon positif atas penjelasan yang disampaikan guru walaupun ada sebagian peserta didik yang tampak kurang memperhatikan. Pada siklus II, telah terjadi peningkatan yang signifikan aktivitas belajar peserta didik untuk KD memahami sensor pada engine bensin. Peningkatan aktivitas tersebut tampak pada beberapa hal, yakni (1) perhatian peserta didik pada proses pembelajaran menjadi lebih baik, (2) keaktifan peserta didik dalam kerja mandiri ataupun kelompok menjadi lebih tinggi, (3) respon peserta didik pada aktivitas pembelajaran menjadi lebih positif, (4) minat belajar peserta didik terbangun melalui interaksi antarteman, (5) motivasi belajar dapat dipertahankan karena adanya lembar kerja yang diberikan, (6) antusiasme dan kegembiraan belajar muncul dalam pembelaaran, (7) keingintahuan peserta 
didik dalam materi yang diajarkan meningkat, (8) rasa tanggung jawab untuk menyelesaikan tugas mulai tampak, dan (9) interaksi dan komunikasi kelas dalam proses pembelajaran lebih kondusif. Peningkatan aktivitas peserta didik, selain disebabkan oleh pembelajaran menerapkan model kerja kelompok dengan teknik jigsaw. Melalui diskusi dan kerja kelompok, peserta didik termotivasi untuk berkolaborasi antarteman untuk mengerjakan tugas yang diberikan oleh guru. Hal ini sesuai dengan pendapat Sanjaya (2007) yang menjelaskan bahwa diskusi adalah proses yang melibatkan dua atau lebih individu yang melakukan komunkasi secara verbal untuk tukarmenukar infomasi, mempertahankan pendapat, dan memacahkan masalah.

Hasil belajar yang dicapai peserta didik pada siklus I telah mengalami peningkatan jika dibandingkan dengan hasil belajar pra siklus. Peningkatan tersebut dapat dilihat dari perbandingan persentase jumlah peserta didik berdasarkan jenjang kemampuan. Hasilnya adalah jumlah peserta didik yang jenjang kemampuannya termasuk kategori (1) tinggi pada pra siklus sebanyak 2 orang (8\%), pada siklus I tetap sebanyak 2 orang (8\%), (2) sedang pada pra siklus sebanyak 4 orang (16\%), pada siklus I meningkat menjadi sebanyak 13 orang (52\%), (3) kurang pada pra siklus sebanyak 13 (52\%), pada siklus I turun menjadi sebanyak 10 orang (40\%), dan (4) tidak mampu pada pra siklus sebanyak 6 orang (24\%), pada siklus I tidak ada peserta didik yang tidak mampu. Sedangkan jenjang kemampuan yang dicapai oleh peserta didik pada siklus II meningkatkan dibandingkan pada siklus I. Hasilnya adalah jumlah peserta didik yang jenjang kemampuannya termasuk kategori (1) tinggi pada siklus I sebanyak 2 orang (8\%), pada siklus II tetap sebanyak 6 orang (24\%), (2) sedang pada siklus I sebanyak 13 orang (52\%), pada siklus II meningkat menjadi sebanyak 17 orang (68\%), (3) kurang pada siklus I sebanyak 10 (40\%), pada siklus II turun menjadi sebanyak 2 orang (8\%), dan (4) tidak mampu pada siklus I sebanyak 0 orang $(0 \%)$, pada siklus II juga sebanyak 0 orang ( $0 \%)$. Hasil belajar yang dicapai peserta didik dari siklus I ke siklus II dengan materi yang berbeda juga mengalami peningkatan yang signifikan. Peningkatan hasil belajar tersebut dapat dilihat dari besaran perolehan skor peserta didik dari siklus I ke siklus II. Hal ini dapat terlihat dari jumlah peserta didik yang dari skor siklus I ke skor siklus II (1) sama dan mencapai ketuntasan sebanyak 5 orang, (2) meningkat dan mencapai ketuntasan sebanyak 18 orang, (3) sama dan belum tuntas sebanyak 1 orang, dan (4) meningkat dan belum tuntas sebanyak 1 orang. Berdasarkan kategori tersebut, dapat disimpulkan bahwa tindakan siklus II telah dapat meningkatkan kemampuan peserta didik dalam memahami materi yang diajarkan. Jadi dengan penerapan model belajar kerja kelompok dengan teknik jigsaw ini dapat mengubah pola belajar peserta didik. Dengan demikian guru mampu "mengajar", yaitu membimbing kegiatan belajar peserta didik sehingga mau belajar (Usman : 21). Dan pemilihan model belajar kerja kelompok dengan teknik jigsaw sudah cocok dengan karateristrik siswa kelas XI Oto (Sanjaya : 131).

\section{KESIMPULAN}

Aktivitas belajar memahami sensor pada engne bensin peserta didik kelas XI Teknik Ototronik SMK Negeri 6 Malang setelah diajar melalui model pembelajaran kerja kelompok dengan teknik mengalami peningkatan. Peningkatan aktivitas tersebut disebabkan oleh adanya pengondisian dan penyesuaian pembelajaran dengan kebutuhan peserta didik yang berkaitan dengan topik materi sensor pada engine bensin yang digunakan dalam pembelajaran dan kebiasaan serta gaya belajar yang dilakukan oleh peserta didik..

Kemampuan memahami sensor pada engne bensin peserta didik kelas XI Teknik Ototronik SMK Negeri 6 Malang meningkat setelah mendapatkan pengalaman belajar melalui model pembelajaran kerja kelompok dengan teknik jigsaw.

\section{DAFTAR PUSTAKA}

Anita, Lie. (2008). Cooperative Learning. Jakarta : Gramedia Widiasarana Indonesia.

Arikunto, Suharsimi. (2002). Penelitian Tindakan Kelas. Jakarta: Bumi Aksara.

Dalyono. (2005). Psikologi Pendididkan, Jakarta: Rineka Cipta.

Hamalik, Oemar. (2003). Kurikulun dan Pembelajaran. Jakarta: Bumi Aksara. 
Moleong , Lexy J. (2007). Metodologi Penelitian Kualitatif. Bandung: Remaja Rosdakarya. Nur, Mohamad. (2005). Pembelajaran Kooperatif. Dirjen Dikti Depdiknas.

Pusat Bahasa Depdiknas. (2002). Kamus Besar Bahasa Indonesia. Jakarta: Balai Pustaka.

Rusman. (2008). Model-Model Pembelajaran Mengembangkan Profesionalisme Guru. Jakarta : Rajawali Pers.

Sanjaya, Wina. (2006). Strategi Pembelajaran. Bandung : Kencana Prenadamedia.

Syah, Muhibbin. (2005). Psikologi Pendidikan: Dengan Pendekatan Baru. Bandung: Remaja Rosdakarya.

Usman, Moh. (2002). Menjadi Guru Profesional. Bandung: Remaja Rosdakarya.

Wiriaatmadja, Rochiati. (2005). Metode Penelitian Tindakan Kelas. Bandung: Remaja Rosdakarya.

https://media.neliti.com/media/publications/293668-pembelajaran-kooperatif-tipe-jigsaw4c298905.pdf 